\title{
EVALUATION OF INFRASTRUCTURE READINESS IN SUPPORTING THE IMPLEMENTATION OF E-GOVERNMENT USING THE COBIT 5 FRAMEWORK. CASE STUDY: PADANGSIDIMPUAN CITY GOVERNMENT
}

\author{
Alfiansyah Halomoan Siregar ${ }^{1}$, dan Irman Hermadi ${ }^{2}$, Sri Wahjuni ${ }^{2}$ \\ ${ }^{1}$ Magister of computer Science in the Computer Science Study Program, Bogor Agricurtural University \\ ${ }^{2}$ Department of computer Science, Bogor Agricurtural University \\ E-mail: alfiansyah_siregar1805@apps.ipb.ac.id
}

\begin{abstract}
The application of information technology (IT) has now become a necessity in all aspects of both individuals, groups or organizations and even government institutions. The implementation of IT in government is a form of execution of the President's instruction No. 3 of 2003 concerning national policies and strategies for the development of e-government. IT infrastructure itself is a foundation and framework that supports a system or organization. Excellent IT infrastructure support will contribute to accelerating the achievement of organizational goals. Evaluation of IT infrastructure readiness in Diskominfo in Padangsidimpuan City is done using the COBIT framework, by measuring the maturity level of IT infrastructure governance that refers to IT management goals number 10 and 11 in COBIT that are mapped on 13 COBIT process domains. The results of the evaluation of the level of achievement in each process there are eight processes at the completion of levels 1 and five are at the achievement of level 0 . The level of hope for achieving the whole process is at level 3 and the gap consists of 2 degrees and 3 levels of achievement. The recommendations given in the form of a SWOT in this study aim to increase the level of maturity of IT infrastructure governance to support the implementation of e-government in the city government of Padangsidimpuan.
\end{abstract}

Keywords: Capability level, COBIT 5, E-Government, Infrastructure

\begin{abstract}
Abstrak
Penerapan teknologi informasi (TI) saat ini telah menjadi kebutuhan di segala aspek baik individual, kelompok atau organisasi bahkan lembaga pemerintahan. Penerapan TI di pemerintahan merupakan bentuk pelaksanaan instruksi Presiden (Inpres) Nomor 3 Tahun 2003 tentang kebijakan dan strategi nasional pengembangan e-government. Infrastruktur TI sendiri adalah suatu pondasi dan kerangka kerja yang mendukung suatu sistem atau organisasi. Dukungan infrastruktur TI yang baik akan memberikan kontribusi pada percepatan pencapaian tujuan organisasi. Evaluasi kesiapan infrastruktur TI di Diskominfo Kota Padangsidimpuan dilakukan menggunakan framework COBIT, dengan mengukur tingkat kematangan tata kelola infrastruktur TI yang mengacu pada tujuan manajemen TI nomor 10 dan 11 dalam COBIT yang dipetakan pada 13 domain proses COBIT. Hasil evaluasi tingkat pencapaian pada setiap proses terdapat 8 proses berada pada pencapaian level 1 dan 5 berada pada pencapaian level 0 . Tingkat harapan untuk mencapai keseluruhan proses berada pada level 3 dan kesenjangan terdiri dari 2 level dan 3 level pencapaian. Rekomendasi yang diberikan dalam bentuk SWOT pada penelitian ini bertujuan untuk meningkatkan tingkat kematangan tata kelola infrastruktur TI untuk mendukung penerapan e-government di pemerintah kota Padangsidimpuan.
\end{abstract}

Kata Kunci: COBIT 5, E-Government, Infrastruktur, Tingkat pencapaian

\section{Introduction}

The application of information technology (IT) has now become a necessity in all aspects of both individuals, groups or organizations and even government institutions [1]. The implementation of IT in government is a form of implementation of the President's instruction (Inpres) No. 3 of 2003 concerning national policies and strategies for the development of e-government. This
Instruction has mandated, to the Governor and Regents / Mayors to take the necessary concrete steps by their respective duties, functions, and authorities, for the implementation of national egovernment development [2].

IT infrastructure is the foundation or framework that supports a system or organization. Excellent IT infrastructure support will contribute to accelerating the achievement of organizational goals, whereas if the infrastructure is not right it 
can hamper the performance of goals. The foundation itself supports the completion of the organization's general goals by facilitating collaboration and integration of resources [3].

The city of Padangsidimpuan was formed in 2001 and currently has six sub-districts consisting of 42 villages and 37 sub-districts [4]. The population of Padangsidimpuan City in 2016 was 212,917 people, male population was 103,709 people, and the female population was 109,208 [5]. Based on the 2016 national socio-economic survey (Susenas) data, the percentage of the population of the city of Padangsidimpuan, aged five years and over, amounting to 190,694 people has accessed the internet. Accessing the internet by residents of the City of Padangsidimpuan per 3 months in 2016 aims to get information or news as much as $95.85 \%$ and only $4.15 \%$ use it for commercial facilities [6]. Based on the high desire of the residents of Padangsidimpuan City to use IT as a means of information in this case the Padangsidimpuan City government is one of the government institutions that are in the process of transformation towards the implementation of IT or what is called e-government to carry out its duties and functions. The application of egovernment which will later serve the people of Padangsidimpuan City to get information or news primarily from the Government. The implementation of e-government certainly has constraints that become obstacles to improving the quality of e-government, including the low level of readiness of IT infrastructure from the Government to implement e-government itself.

Evaluation of the readiness of IT infrastructure in the City Government of Padangsidimpuan is done to provide recommendations in supporting the implementation of e-government. Evaluation is done by measuring the maturity level of IT infrastructure governance. Measures from the achievement of right information technology (infrastructure) management can be done with a scientific approach, one of them is by using the COBIT framework reference (control objectives for information and related technology). COBIT is an IT management guide standard and a set of documentation for IT governance best practices. COBIT can help auditors, leaders, and users to bridge the gap between business risk, control needs, and technical issues. The recommendations in this study are compiled based on the results of measurement of the maturity level of IT governance. Then a SWOT analysis was carried out [7] to determine the strengths, weaknesses, opportunities, and threats of IT infrastructure in the city government in the enumeration area.

\section{Literature Review}

\section{Padangsidimpuan City}

Related to the research that will be conducted is based on mission number 4 of the Padangsidimpuan City Government on improving the quality and infrastructure addressed to Diskominfo based on the leading performance indicators of the Padangsidimpuan City Government in 2014-2020 can be seen in Table 1.

TABLE 1

\begin{tabular}{cllc}
\multicolumn{3}{c}{ MAIN PERFORMANCE INDICATORS } \\
\hline Mission & Target & \multicolumn{1}{c}{ Goals } & $\begin{array}{c}\text { Person in } \\
\text { charge }\end{array}$ \\
\hline $\begin{array}{clll}\text { Number } \\
4\end{array}$ & $\begin{array}{l}\text { Realizing } \\
\text { quality } \\
\text { infrastruc- } \\
\text { ture }\end{array}$ & $\begin{array}{l}\text { • Increasing sources } \\
\text { of information to the } \\
\text { community }\end{array}$ & $\begin{array}{c}\text { Disko- } \\
\text { minfo }\end{array}$ \\
& $\begin{array}{l}\text { Produce } \\
\text { recommendations } \\
\text { for information and } \\
\end{array}$ & communication \\
& & \\
& & \\
& &
\end{tabular}

\section{IT infrastructure}

IT infrastructure is infrastructure and facilities that involve networks, computers, hardware, and other software. IT infrastructure is also the foundation of IT services, without an IT infrastructure the service will not work correctly. How high the IT capabilities of an organization can be seen from how far the organization can deploy its infrastructure.

The concept of developing e-government infrastructure based on Presidential Instruction number 3 of 2003 [8], the development of egovernment in a government institution is based on four central foundations, including:

a. The e-government superstructure which includes, among others, institutional management leadership (e-leadership), human resources and regulations at the institutional level related to e-government (regulation) development.

b. Infrastruktur jaringan yang memuat antara lain protokol komunikasi, topologi, teknologi dan keamanan.

c. Network infrastructure that includes communication protocols, topology, technology, and security.

d. Application infrastructure includes applications for public services, interface applications, and back-office applications.

The evaluation conducted in this study focuses on knowing the level of readiness of IT infrastructure in the City Government of Padangsidimpuan towards the four main foundations above. 


\section{COBIT 5}

COBIT 5 is the latest generation of ISACA guidelines that discuss IT governance and management [9]. COBIT 5 defines and explains in detail many governances and process management. COBIT 5 also provides a framework for measuring and monitoring IT performance.

TABLE 2

COBIT 5 IT-RELATED GOALS (ISACAB 21012)

\begin{tabular}{|c|c|c|}
\hline & & IT Related Goals \\
\hline \multirow[t]{6}{*}{ Finance } & 01 & $\begin{array}{l}\begin{array}{l}\text { Alignment of IT and business } \\
\text { strategies. }\end{array}\end{array}$ \\
\hline & 02 & $\begin{array}{l}\text { IT adjustment and support for } \\
\text { business suitability with external } \\
\text { laws and regulations. }\end{array}$ \\
\hline & 03 & $\begin{array}{l}\text { Executive management commitment } \\
\text { to making decisions related to IT. }\end{array}$ \\
\hline & 04 & Managed IT related to business risks. \\
\hline & 05 & $\begin{array}{l}\text { Benefits realized from investments } \\
\text { and portfolio of services supported } \\
\text { by IT. }\end{array}$ \\
\hline & 06 & $\begin{array}{l}\text { Transparency of IT costs, benefits } \\
\text { and risks. }\end{array}$ \\
\hline \multirow[t]{2}{*}{ User } & 07 & 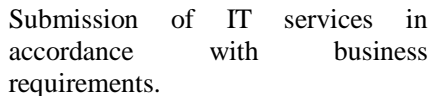 \\
\hline & 08 & $\begin{array}{l}\text { Adequate use of applications, } \\
\text { information and technology } \\
\text { solutions. }\end{array}$ \\
\hline \multirow[t]{7}{*}{ Internal } & 09 & IT intelligence. \\
\hline & 10 & $\begin{array}{l}\text { Information security, infrastructure } \\
\text { and application processing. }\end{array}$ \\
\hline & 11 & $\begin{array}{l}\text { Optimization of assets, resources, } \\
\text { and IT capabilities. }\end{array}$ \\
\hline & 12 & $\begin{array}{l}\text { Empowering and supporting business } \\
\text { processes by integrating applications } \\
\text { and technology into business } \\
\text { processes. }\end{array}$ \\
\hline & 13 & $\begin{array}{l}\text { Submission of programs that provide } \\
\text { benefits, on time, on budget, and } \\
\text { meet quality requirements and } \\
\text { standards. }\end{array}$ \\
\hline & 14 & $\begin{array}{l}\text { Availability of reliable and useful } \\
\text { information for decision making. }\end{array}$ \\
\hline & 15 & IT compliance with internal policies. \\
\hline $\begin{array}{l}\text { Learning } \\
\text { and }\end{array}$ & 16 & $\begin{array}{l}\text { Business and IT personnel who are } \\
\text { competent and motivated. }\end{array}$ \\
\hline $\begin{array}{l}\text { developm } \\
\text { ent }\end{array}$ & 17 & $\begin{array}{l}\text { Knowledge, expertise initiatives for } \\
\text { business innovation. }\end{array}$ \\
\hline
\end{tabular}

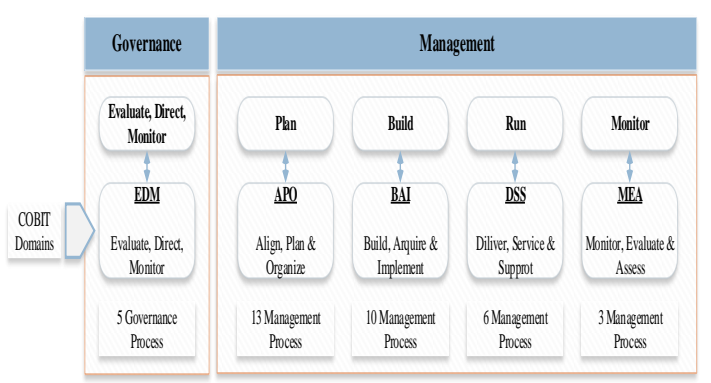

Figure 1. process in COBIT 5 (ISACAb 2012)
COBIT 5 establishes 17 IT-related Goals targets can be seen in Table 2 and identifies 37 IT processes seen in Figure 1 where the governance domain of 5 methods and management as many as 32 means to support the utilization of IT in an organization to align with the organization's business objectives [10].

\section{Related research}

Research related to IT infrastructure has been conducted by Hadi (2014) measuring the level of governance capabilities of the Gorontalo Provincial Government network infrastructure that was built in 2013 to connect 51 points consisting of 31 agency points, 10 points of regional service units, 3 Regency / City points and 6 hotspot points in public places using the COBIT 5 framework framework [11]. Subsequent research was conducted by Rahma (2017) which aims to evaluate the level of readiness of integrated sub-district administrative service infrastructure (PATEN) to support local egovernment in the Bogor City government using the COBIT 5 framework [12]. Research on IT infrastructure was also carried out by Friyonanda (2017) evaluating the governance of IPB's information technology infrastructure by measuring the level of IT maturity using the COBIT 5 framework [13].

\section{Method}

This research was carried out following the frame of mind shown in Figure 2.

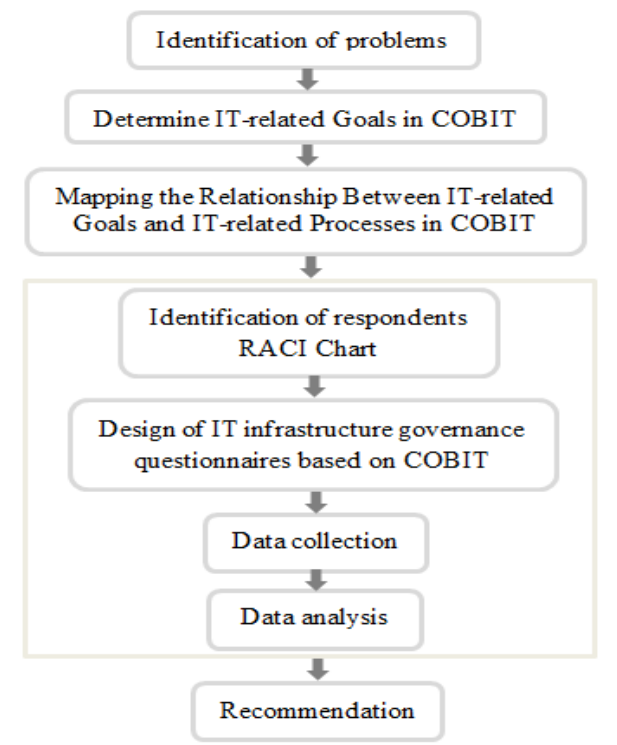

Figure 2. Framework of thinking 
Mapping the Relationship Between IT-related Goals and IT-related Processes in COBIT

The processes related to IT-related goals 10 and 11 are based on COBIT enabling processes (ISACA 2012) [14] shown in Table 3. They are then mapped to the process that fits the research needs carried out, concerning mission number 4 Padangsidimpuan City Government which aims to realize quality infrastructure. The planned process can be seen in Table 4 .

TABLE 3

IT-RELATED GOALS AND IT-RELATED PROCESS

\begin{tabular}{|c|c|}
\hline $\begin{array}{l}\text { IT-related } \\
\text { Goals }\end{array}$ & IT-related Process \\
\hline 10 & $\begin{array}{l}\text { EDM03, APO12, APO13, BAI06, DSS05 } \\
\text { EDM04, APO01, APO03, APO04, APO07 }\end{array}$ \\
\hline 11 & $\begin{array}{l}\text { BAI04, BAI09, BAI10, DSS01, DSS03, } \\
\text { MEA01 }\end{array}$ \\
\hline
\end{tabular}

TABLE 4

MAPPING IT RELATED-GOALS WITH IT-RELATED PROCESS

\begin{tabular}{|c|c|c|c|c|}
\hline No & Area & Domain & & Process \\
\hline 1 & $G$ & $\begin{array}{l}\text { Evaluate, } \\
\text { Direct } \\
\text { and } \\
\text { Monitor }\end{array}$ & EDM04 & $\begin{array}{l}\text { Ensure Resource } \\
\text { Optimisation }\end{array}$ \\
\hline \multirow[t]{12}{*}{2} & $M$ & $\begin{array}{l}\text { Align, } \\
\text { Plan and } \\
\text { Organise }\end{array}$ & APO01 & $\begin{array}{l}\text { Manage the IT } \\
\text { Managemen } \\
\text { Framework }\end{array}$ \\
\hline & & & APO07 & $\begin{array}{ll}\text { Manage Human } \\
\text { Resources }\end{array}$ \\
\hline & & & APO12 & Manage Risk \\
\hline & & & APO13 & Manage Security \\
\hline & & $\begin{array}{l}\text { Build, } \\
\text { Acquire } \\
\text { and }\end{array}$ & BAI04 & $\begin{array}{l}\text { Manage } \\
\text { Availability and } \\
\text { Capacity }\end{array}$ \\
\hline & & Implement & BAI06 & Manage Changes \\
\hline & & & BAI09 & Manage Assets \\
\hline & & & BAI10 & $\begin{array}{l}\text { Manage } \\
\text { Configuration }\end{array}$ \\
\hline & & Deliver, & DSS01 & Manage Operations \\
\hline & & Service & DSS03 & Manage Problems \\
\hline & & $\begin{array}{l}\text { and } \\
\text { Support }\end{array}$ & DSS05 & Manage Continuity \\
\hline & & $\begin{array}{l}\text { Monitor, } \\
\text { Evaluate } \\
\text { And } \\
\text { Assess }\end{array}$ & MEA01 & $\begin{array}{l}\text { Control assessment } \\
\text { and performance } \\
\text { evaluation }\end{array}$ \\
\hline
\end{tabular}

\section{Level Achievement}

The level of governance of IT infrastructure is measured to determine the extent of management of IT infrastructure. Measuring scale uses PAM (process assessment model) at COBIT 5. Maturity levels are divided into six levels from 0 to 5 . Each level has different criteria; the assessment carried out based on achievement (output) of Process Attribute (PA) is shown in Table 5.

Each process attribute is measured using an ISO / IEC 15504 rating scale which is divided into four scales, as shown in Table 6 . A process can be stated to have reached maturity value, just by obtaining an achieved total criteria value of 50$85 \%$ achievement or fully completed with an amount of $85-100 \%$ achievement. Then to be declared able to proceed to the next capability level, it must fulfill the fully achieved category of $100 \%$ achievement from the previous level determined by the ISO / IEC 15504 criteria.

TABLE 5

LEVEL OF MATURITY PROCESS (ISACAB 2012)

\begin{tabular}{|c|c|c|c|}
\hline \multirow[t]{2}{*}{$\mathrm{L}$} & \multirow[t]{2}{*}{ Description } & \multicolumn{2}{|c|}{ Attribute Process } \\
\hline & & PA.1 & PA.2 \\
\hline 0 & $\begin{array}{l}\text { The process is not } \\
\text { implemented or } \\
\text { there is no effort to } \\
\text { reach the goal. }\end{array}$ & - & - \\
\hline 1 & $\begin{array}{l}\text { The process is } \\
\text { implemented on an } \\
\text { ad-hoc basis to } \\
\text { achieve the process } \\
\text { objectives. }\end{array}$ & $\begin{array}{l}\text { Process } \\
\text { Performance }\end{array}$ & - \\
\hline 2 & $\begin{array}{l}\text { he process has been } \\
\text { implemented and } \\
\text { managed } \\
\text { planned } \\
\text { monith } \\
\text { and } \\
\end{array}$ & $\begin{array}{l}\text { Performance } \\
\text { Management }\end{array}$ & $\begin{array}{l}\text { Work } \\
\text { Product } \\
\text { Management }\end{array}$ \\
\hline 3 & $\begin{array}{l}\text { The process is } \\
\text { implemented by } \\
\text { default and has been } \\
\text { standardized. }\end{array}$ & $\begin{array}{l}\text { Process } \\
\text { Definition }\end{array}$ & $\begin{array}{l}\text { Process } \\
\text { Deployment }\end{array}$ \\
\hline 4 & $\begin{array}{l}\text { he process is } \\
\text { implemented with } \\
\text { certain limitations } \\
\text { in order to be } \\
\text { consistent } \\
\text { achieving in } \\
\text { results that have } \\
\text { been set. }\end{array}$ & $\begin{array}{l}\text { Process } \\
\text { Measurement }\end{array}$ & $\begin{array}{l}\text { Process } \\
\text { Control }\end{array}$ \\
\hline 5 & $\begin{array}{l}\text { he process is } \\
\text { continuously } \\
\text { evaluated and } \\
\text { corrected. }\end{array}$ & $\begin{array}{l}\text { Process } \\
\text { Innovation }\end{array}$ & $\begin{array}{l}\text { Process } \\
\text { Optimisation }\end{array}$ \\
\hline \multicolumn{4}{|c|}{$\begin{array}{l}\text { Description: L = level, } 0=\text { Incomplete, } 1=\text { Performed, } 2= \\
\text { Managed, } 3=\text { Established, } 4=\text { Predictable dan } 5 \text { Optimizing }\end{array}$} \\
\hline \multicolumn{4}{|c|}{$\begin{array}{c}\text { TABLE } 6 \\
\text { ASSESSMENT SCALA ISO/IEC } 15504 \text { (ISACAC 2012) }\end{array}$} \\
\hline & $\begin{array}{ll}\text { cale } & \text { Inform }\end{array}$ & tion $\quad A$ & ievement $\%$ \\
\hline & Not Ach & eved & $0-14$ \\
\hline & Partially $A$ & chieved & $15-49$ \\
\hline & Largely $A$ & hieved & $50-84$ \\
\hline & Fully Ac & ieved & $85-100$ \\
\hline
\end{tabular}

Criteria assessment uses the Guttman scale approach with the answer "Yes" if the process has been run the same as the score 1 and the answer "No" equals the score 0. Determination of maturity level is used with the approach of Equation 1.

$C C=\frac{\Sigma C L a}{\Sigma P_{o}} \times 100 \%$ 
Description:

$\mathrm{CC}$ : Value of achievement at each level or process attribute at each level.

$\Sigma$ CLa : The total value for each level or processattribute at each level.

$\Sigma P o \quad:$ Number of criteria for questions at each level or process attributes at each level.

\section{Identification RACI Chart}

Stakeholders selected as respondents in this study who represent RACI tables (responsible, accountable, consulted, and informed) [15] which are determined based on the Padomidimpuan City Diskominfo organizational structure.

\section{Infrastruktur Infrastructure Governance Questionnaire}

The questionnaire in this research was designed to determine the level of maturity and expectation in each process of managing IT infrastructure by looking at Stakeholder responses. So that it can be seen the comparison between the conditions experienced at this time in the hope of achieving the desired in the future. The preparation of this questionnaire is based on the COBIT 5 framework guide (ISACAd 2012) [16].

\section{Data collection}

Data collection was done by distributing questionnaires according to respondents who had been identified based on the respondent's RACI chart. Data collection was conducted at the Office of communication and informatics (Diskominfo) in the City of Padangsidimpuan. Data collected based on questionnaires that have been distributed to determine the level of readiness of IT infrastructure in Diskominfo, Padangsidimpuan City.

\section{Results and Discussion}

\section{Level Achievement}

The results of measuring the maturity level of IT infrastructure management in Diskominfo in Padangsidimpuan City are determined from the achievement of each process shown in Table 7. They are measuring the level of performance of maturity using the ISO / IEC 15504 criteria according to the COBIT process and scale calculation using Equation 1.

\section{Achievement Expectation Level}

Table 8 shows the achievement values in each process where APO01, APO07, APO13, BAI09, BAI10, DSS01, DSS03 and DSS05 are at level 1. Achievements in the EDM04, APO12, BAI04, BAI06, and MEA 01 processes are at level achievement 0 . The expected value of progress in all means is at level 3 .

\section{Level of Gap}

This level of inequality is derived from the comparison of the current process position (As is) and future expectations (To be). Comparison of the process with the level of the gap is in the values 2, and three can be seen in Figure 3. The gap value is obtained from the value of the current position minus the expectation value. This level of disparity is carried out to determine the extent to which the process needs to be improved to achieve the desired level of maturity. The level of the gap (GAP) in this study can be seen in Table 9.

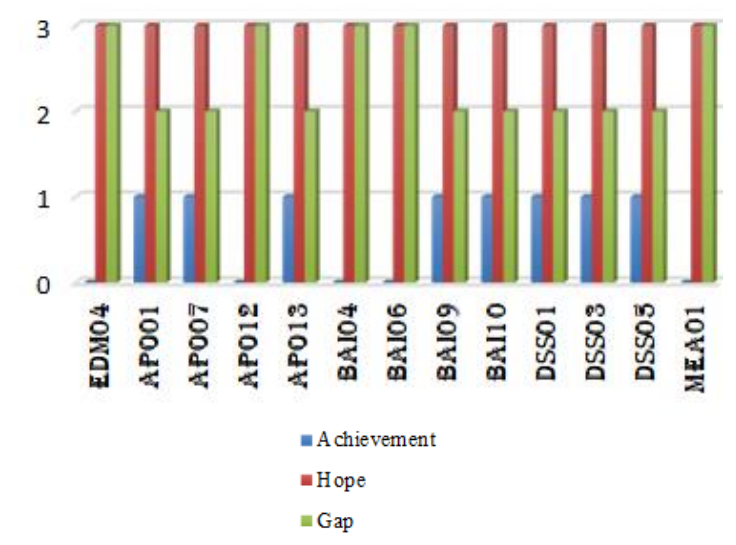

Figure 3. Gaps level

\section{Recommendation}

Recommendations are made by compiling a series of activities to improve the IT service process based on the level of achievement obtained from the method of achieving the maturity level of IT infrastructure governance in Padomidimpuan City Diskominfo using COBIT. Recommendations, in general, are arranged in the form of a SWOT matrix [17] which separates strengths, weaknesses, opportunities, and threats to the implementation of e-government, especially in Diskominfo, Padangsidimpuan City can be seen in Table 10. 
Based on the results of the achievements in Table 7 with the gaps obtained in Table 9, some strengths and weaknesses will be used to be used as references in providing recommendations. Develop a series of strategies to improve the opportunities that can be done to improve the quality of management related to IT infrastructure and several threats that will be obtained. Determine the strengths and weaknesses based on the management process that has been carried out by Diskominfo in Padangsidimpuan City. A series of management processes related to IT infrastructure was asked in the form of a questionnaire. Determine opportunities that can be done based on management processes that have not yet been implemented and determine threats based on the weaknesses obtained. Then from the results of the SWOT analysis of the strengths, weaknesses, opportunities, and threats of eating, a series of recommendations or improvements is made between the strengths of opportunities, weaknesses in opportunities, strengths of threats and weaknesses of threats. Recommendations or strategies are given to become recommendations for Padangsidimpuan City Diskominfo to support the implementation of IT or what is called egovernment.

TABLE 7

LEVEL ACHIEVEMENT

\begin{tabular}{|c|c|c|c|c|c|c|c|c|c|c|c|}
\hline \multirow{2}{*}{$\begin{array}{c}\text { Level } \\
\text { PA }\end{array}$} & \multirow[t]{2}{*}{ 0 } & 1 & \multicolumn{2}{|c|}{2} & \multicolumn{2}{|c|}{3} & \multicolumn{2}{|c|}{4} & \multicolumn{2}{|c|}{5} & \multirow{2}{*}{ CP } \\
\hline & & 1 & 2.1 & 2.2 & 3.1 & 3.2 & 4.1 & 4.2 & 5.1 & 5.2 & \\
\hline \multirow{2}{*}{ EDM 04} & False & $67 \%$ & $50 \%$ & $25 \%$ & $0 \%$ & $0 \%$ & $0 \%$ & $0 \%$ & $0 \%$ & $0 \%$ & \multirow{2}{*}{ O } \\
\hline & & $\mathrm{L}$ & $\mathrm{L}$ & $\mathrm{P}$ & $\mathrm{N}$ & $\mathrm{N}$ & $\mathrm{N}$ & $\mathrm{N}$ & $\mathrm{N}$ & $\mathrm{N}$ & \\
\hline \multirow{2}{*}{ APO 01} & False & $100 \%$ & $80 \%$ & $50 \%$ & $20 \%$ & $0 \%$ & $0 \%$ & $0 \%$ & $0 \%$ & $0 \%$ & \multirow{2}{*}{1} \\
\hline & & $\mathrm{F}$ & $\mathrm{L}$ & $\mathrm{L}$ & $\mathrm{P}$ & $\mathrm{N}$ & $\mathrm{N}$ & $\mathrm{N}$ & $\mathrm{N}$ & $\mathrm{N}$ & \\
\hline \multirow{2}{*}{ APO 07} & False & $100 \%$ & $83 \%$ & $50 \%$ & $0 \%$ & $0 \%$ & $0 \%$ & $0 \%$ & $0 \%$ & $0 \%$ & \multirow{2}{*}{1} \\
\hline & & $\mathrm{F}$ & $\mathrm{L}$ & $\mathrm{L}$ & $\mathrm{N}$ & $\mathrm{N}$ & $\mathrm{N}$ & $\mathrm{N}$ & $\mathrm{N}$ & $\mathrm{N}$ & \\
\hline \multirow{2}{*}{ APO 12} & False & $25 \%$ & $17 \%$ & $0 \%$ & $0 \%$ & $0 \%$ & $0 \%$ & $0 \%$ & $0 \%$ & $0 \%$ & \multirow{2}{*}{$\mathbf{0}$} \\
\hline & & $\mathrm{P}$ & $\mathrm{P}$ & $\mathrm{N}$ & $\mathrm{N}$ & $\mathrm{N}$ & $\mathrm{N}$ & $\mathrm{N}$ & $\mathrm{N}$ & $\mathrm{N}$ & \\
\hline \multirow{2}{*}{ APO 13} & False & $100 \%$ & $50 \%$ & $50 \%$ & $40 \%$ & $33 \%$ & $0 \%$ & $0 \%$ & $0 \%$ & $0 \%$ & \multirow{2}{*}{1} \\
\hline & & $\mathrm{F}$ & $\mathrm{L}$ & $\mathrm{L}$ & $\mathrm{P}$ & $\mathrm{P}$ & $\mathrm{N}$ & $\mathrm{N}$ & $\mathrm{N}$ & $\mathrm{N}$ & \\
\hline \multirow{2}{*}{ BAI 04} & False & $67 \%$ & $50 \%$ & $25 \%$ & $0 \%$ & $0 \%$ & $0 \%$ & $0 \%$ & $0 \%$ & $0 \%$ & \multirow{2}{*}{ 0 } \\
\hline & & $\mathrm{L}$ & $\mathrm{L}$ & $\mathrm{P}$ & $\mathrm{N}$ & $\mathrm{N}$ & $\mathrm{N}$ & $\mathrm{N}$ & $\mathrm{N}$ & $\mathrm{N}$ & \\
\hline \multirow{2}{*}{ BAI 06} & False & $75 \%$ & $67 \%$ & $25 \%$ & $0 \%$ & $0 \%$ & $0 \%$ & $0 \%$ & $0 \%$ & $0 \%$ & \multirow{2}{*}{$\mathbf{0}$} \\
\hline & & $\mathrm{L}$ & $\mathrm{L}$ & $\mathrm{P}$ & $\mathrm{N}$ & $\mathrm{N}$ & $\mathrm{N}$ & $\mathrm{N}$ & $\mathrm{N}$ & $\mathrm{N}$ & \\
\hline \multirow{2}{*}{ BAI 09} & False & $100 \%$ & $67 \%$ & $25 \%$ & $0 \%$ & $0 \%$ & $0 \%$ & $0 \%$ & $0 \%$ & $0 \%$ & \multirow{2}{*}{1} \\
\hline & & $\mathrm{F}$ & $\mathrm{L}$ & $\mathrm{P}$ & $\mathrm{N}$ & $\mathrm{N}$ & $\mathrm{N}$ & $\mathrm{N}$ & $\mathrm{N}$ & $\mathrm{N}$ & \\
\hline \multirow{2}{*}{ BAI 10} & False & $100 \%$ & $67 \%$ & $0 \backslash \%$ & $0 \%$ & $0 \%$ & $0 \%$ & $0 \%$ & $0 \%$ & $0 \%$ & \multirow{2}{*}{1} \\
\hline & & $\mathrm{F}$ & $\mathrm{L}$ & $\mathrm{N}$ & $\mathrm{N}$ & $\mathrm{N}$ & $\mathrm{N}$ & $\mathrm{N}$ & $\mathrm{N}$ & $\mathrm{N}$ & \\
\hline \multirow{2}{*}{ DSS 01} & False & $100 \%$ & $50 \%$ & $25 \%$ & $0 \%$ & $0 \%$ & $0 \%$ & $0 \%$ & $0 \%$ & $0 \%$ & \multirow{2}{*}{1} \\
\hline & & $\mathrm{F}$ & $\mathrm{L}$ & $\mathrm{P}$ & $\mathrm{N}$ & $\mathrm{N}$ & $\mathrm{N}$ & $\mathrm{N}$ & $\mathrm{N}$ & $\mathrm{N}$ & \\
\hline \multirow{2}{*}{ DSS 03} & False & $100 \%$ & $67 \%$ & $25 \%$ & $0 \%$ & $0 \%$ & $0 \%$ & $0 \%$ & $0 \%$ & $0 \%$ & \multirow{2}{*}{1} \\
\hline & & $\mathrm{F}$ & $\mathrm{L}$ & $\mathrm{P}$ & $\mathrm{N}$ & $\mathrm{N}$ & $\mathrm{N}$ & $\mathrm{N}$ & $\mathrm{N}$ & $\mathrm{N}$ & \\
\hline DSS 05 & False & $100 \%$ & $67 \%$ & $0 \%$ & $0 \%$ & $0 \%$ & $0 \%$ & $0 \%$ & $0 \%$ & $0 \%$ & 1 \\
\hline DSS UD & & $\mathrm{F}$ & $\mathrm{L}$ & $\mathrm{N}$ & $\mathrm{N}$ & $\mathrm{N}$ & $\mathrm{N}$ & $\mathrm{N}$ & $\mathrm{N}$ & $\mathrm{N}$ & 1 \\
\hline MEA 01 & False & $60 \%$ & $50 \%$ & $50 \%$ & $25 \%$ & $0 \%$ & $0 \%$ & $0 \%$ & $0 \%$ & $0 \%$ & 0 \\
\hline & & $\mathrm{L}$ & $\mathrm{L}$ & $\mathrm{L}$ & $\mathrm{P}$ & $\mathrm{N}$ & $\mathrm{N}$ & $\mathrm{N}$ & $\mathrm{N}$ & $\mathrm{N}$ & 0 \\
\hline
\end{tabular}

Dep: $\mathrm{PA}=$ proses atribut, $\mathrm{CP}=$ capability, $\mathrm{F}=$ fully achieved, $\mathrm{L}=$ largely achieved, $\mathrm{P}=$ partially achieved, $\mathrm{N}=$ not achieved. 
TABLE 9

GAPS LEVEL

\begin{tabular}{clccc}
\hline Id & \multicolumn{1}{c}{ Process } & Achievement & Hope & Gap \\
\hline EDM04 & Ensure Resource Optimisation & 0 & 3 & $\mathbf{3}$ \\
APO01 & Manage the IT Managemen Framework & 1 & 3 & $\mathbf{2}$ \\
APO07 & Manage Human Resources & 1 & 3 & $\mathbf{2}$ \\
APO12 & Manage Risk & 0 & 3 & $\mathbf{3}$ \\
APO13 & Manage Security & 1 & 3 & $\mathbf{2}$ \\
BAI04 & Manage Availability and Capacity & 0 & 3 & $\mathbf{3}$ \\
BAI06 & Manage Changes & 0 & 3 & $\mathbf{3}$ \\
BAI09 & Manage Assets & 1 & 3 & $\mathbf{2}$ \\
BAI10 & Manage Configuration & 1 & 3 & $\mathbf{2}$ \\
DSS01 & Manage Operations & 1 & 3 & $\mathbf{2}$ \\
DSS03 & Manage Problems & 1 & 3 & $\mathbf{2}$ \\
DSS05 & Manage Continuity & 1 & 3 & $\mathbf{2}$ \\
MEA01 & Control assessment and performance evaluation & 0 & 3 & $\mathbf{3}$ \\
\hline
\end{tabular}

TABLE 8

ACHIEVEMENT EXPECTATION LEVEL

\begin{tabular}{|c|c|c|c|c|c|c|c|c|c|c|c|c|}
\hline \multirow{2}{*}{\multicolumn{2}{|c|}{ Process }} & \multicolumn{5}{|c|}{ Achievement } & \multicolumn{6}{|c|}{ Hope } \\
\hline & & $\mathbf{0}$ & 1 & 2 & 34 & 5 & $\mathbf{0}$ & 1 & 2 & 3 & 4 & 5 \\
\hline EDM04 & Ensure Resource Optimisation & $\boldsymbol{v}$ & & & & & & & & $\boldsymbol{\nu}$ & & \\
\hline APO01 & Manage the IT Managemen Framework & & $\boldsymbol{\nu}$ & & & & & & & $\boldsymbol{v}$ & & \\
\hline APO07 & Manage Human Resources & & $\checkmark$ & & & & & & & $\checkmark$ & & \\
\hline APO12 & Manage Risk & $\boldsymbol{v}$ & & & & & & & & $\checkmark$ & & \\
\hline APO13 & Manage Security & & $\boldsymbol{v}$ & & & & & & & $\checkmark$ & & \\
\hline BAI04 & Manage Availability and Capacity & $\boldsymbol{v}$ & & & & & & & & $\checkmark$ & & \\
\hline BAI06 & Manage Changes & $\checkmark$ & & & & & & & & $\checkmark$ & & \\
\hline BAI09 & Manage Assets & & $\boldsymbol{v}$ & & & & & & & $\boldsymbol{\nu}$ & & \\
\hline BAI10 & Manage Configuration & & $\checkmark$ & & & & & & & $\boldsymbol{v}$ & & \\
\hline DSS01 & Manage Operations & & $\checkmark$ & & & & & & & $\checkmark$ & & \\
\hline DSS03 & Manage Problems & & $\checkmark$ & & & & & & & $\checkmark$ & & \\
\hline DSS05 & Manage Continuity & & $\checkmark$ & & & & & & & $\checkmark$ & & \\
\hline MEA01 & Control assessment and performance evaluation & $\boldsymbol{v}$ & & & & & & & & $\checkmark$ & & \\
\hline
\end{tabular}

\section{Conclusions and recommendations}

\section{Conclusions}

The evaluation results of the achievement level of 13 processes in the value of Padangsidimpuan City Diskominfo are eight processes, namely: APO01, APO07, APO13, BAI09, BAI10, DSS01, DSS03, and DSS05 are at level 1. Then five methods are: EDM04, APO12, BAI04, BAI06, and MEA01 are at level 0 achievement. The expected value of progress in the whole process is at level 3 with gaps at two levels and three levels of performance. The recommendations are given in the form of a SWOT in this study aim to provide recommendations to improve the maturity level of IT infrastructure governance to support the implementation of e-government, especially in the City Government of Padangsidimpuan.

\section{Recommendations}

Suggestions that can be given to this research are as follows:

1. Ensuring the results of recommendations given in this study can be used and become input to the Padangsidimpuan City Information Center to improve the level of maturity of governance, especially IT infrastructure.

2. To improve the process for each agency, it can be done with a process that is considered priority by using a priority matrix. 
TABLE 10

SWOT RECOMMENDATION

\begin{tabular}{|c|c|c|}
\hline & Strengths & Weaknesses \\
\hline Threats & Strategy ST & Strategy WT \\
\hline $\begin{array}{l}\text { - Physical security of infrastructure, data, } \\
\text { and information. } \\
\text { - Increased costs for improving IT } \\
\text { infrastructure and operational costs. } \\
\text { - Decreased trust in IT users. } \\
\text { - Decrease the quality of performance } \\
\text { towards HR.. }\end{array}$ & $\begin{array}{l}\text { - Improve security systems both internally } \\
\text { and externally. } \\
\text { - Control and supervise every operational } \\
\text { activity. } \\
\text { - Determine priorities that must be } \\
\text { achieved first. } \\
\text { - Implement shared infrastructure use. } \\
\text { - Provide information as needed. }\end{array}$ & $\begin{array}{l}\text { - Document the activities and } \\
\text { changes related to security. } \\
\text { - Define each process and service. } \\
\text { - Determine the scope, limits, } \\
\text { minimum achievement standards } \\
\text { for each operational operation. } \\
\text { - Evaluate and improve each change. } \\
\text { - Resolve problems well and on } \\
\text { time. }\end{array}$ \\
\hline
\end{tabular}




\section{References}

[1] Direktorat e-government. 2014. Buku Petunjuk Penyusunan Rencana Induk egovernment Indonesia. Jakarta. Kemenkominfo RI.

[2] Intruksi Presiden. 2003. Kebijakan dan strategi National Pengembangan egovernment No 3. Indonesia. Jakarta, Sekretariat Negara.

[3] Straube C, Kranzlmuller D. 2013. An ITInfrastructure capability model. Proceedings of the ACM International Conference on Computing Frontiers- CF'13; 2013 Mei 1416; Ischia, IT. New York (US): ACM.

[4] Badan Perencanaan Pembangunan Daerah Kota Padangsidimpuan. 2015. Profil Daerah Kota Padangsidimpuan. Padangsisdimpuan. Bappeda kota padangsidimpuan.

[5] Badan Pusat Statistik Kota Padangsidimpuan. 2017. Statistik Daerah Kota Padangsidimpuan. Padangsidimpuan. BPS Kota Padangsdimpauan Publikasi: 12770.17.16

[6] Survei sosial ekonomi nasional. 2016. Sensus Ekonomi 2016 Analisis Hasil Listing Potensi Ekonomi Kota Padangsidimpuan. Padangsidimpuan. BPS kota Padangsidimpuan Publikasi: 12770.17.16.

[7] Salah K. 2015. A SWOT analysis of TSV: strengths, weaknesses, opportunities, and threats. Di dalam: International Conference on Microelectronics (ICM); 2015 Dec 2023; Danvers (MA): IEEE. hlm 214-217.

[8] Kementerian Komunikasi dan Informasi Republik Indonesia. 2003. Panduan Penyusunan Rencana Induk Pengembangan e-government Lembaga. Versi 1. Indonesia. Jakarta, Kemenkominfo RI.

[9] Information System Audit and Control Association (ISACAa). 2012. COBIT 5: A
Business Framework for the Governance and Management of Enterprise IT. Rolling Meadows (US) : ISACA.

[10] Information System Audit and Control Association (ISACAb). 2012. COBIT 5: Process Assessment Model. Rolling Meadows (US) : ISACA.

[11] Hadi NSS. 2014. Pengukuran Tingkat Kapabilitas Tata Kelola Infrastruktur Jaringan Pemerintah Daerah Provinsi Gorontalo. [JNTETI] Jurnal Nasional Teknik Elektro dan Teknologi Informasi. Indonesia. Yogyakarta (ID) : UGM.

[12] Rahma Y. 2017. Evaluasi Tingkat Kesiapan Infrastruktur TI PEMKOT Bogor Dalam Menunjang Penerapan e-government (studi kasus : Pelayanan Administrasi Terpadu Kecamatan)[Tesis]. Institut Pertanian Bogor. Bogor. Bogor (ID): IPB Pr.

[13] Fryonanda H. 2017. Evaluasi Tata Kelola Infrastruktur Teknologi Informasi IPB Dengan Framework COBIT 5 dan ITIL V3 2011 [Tesis]. Institut Pertanian Bogor. Bogor. Bogor (ID): IPB Pr.

[14] Information System Audit and Control Association (ISACAc). 2012. COBIT 5: Enabling Processes. Rolling Meadows (US) : ISACA.

[15] IT Governance Institute. 2007. COBIT 4.1. Rolling Meadows (US) : ITGI

[16] Information System Audit and Control Association (ISACAd). 2012. COBIT 5: self-Assesment Guide: Using COBIT 5. Rolling Meadows (US) : ISACA.

[17] Penzel D, Natalia K, Michal G. 2015. The future of cloud computing: A SWOT analysis and predictions of development. Di dalam: International Conference on Future Internet of Things and Cloud; 2015 Aug 2426; Danvers (MA): IEEE. hlm 391-397. 